\title{
Oxabicyclo[3.2.1]octane Derivatives as Highly Reactive Dienophiles: Synthesis of Bicyclo[5.n.0] Systems
}

\author{
Phillip M. Pelphrey ${ }^{\dagger}$, Jerry P. Jasinski ${ }^{\ddagger}$, Ray J. Butcher ${ }^{\rrbracket}$ and Dennis L. Wright* ${ }^{\dagger}$ \\ ${ }^{\dagger}$ Burke Laboratories, Department of Chemistry, Dartmouth College, Hanover, NH 03755. \\ ${ }^{\ddagger}$ Department of Chemistry, Keene State College, Keene, NH 03435 \\ "Department of Chemistry, Howard University, Washington, D.C. 20059 \\ Supporting Information
}

General. The ${ }^{1} \mathrm{H}$ and ${ }^{13} \mathrm{C}$ spectra were recorded at 500 and $125 \mathrm{MHz}$ respectively. All melting points are uncorrected. High-resolution mass spectrometry was provided by the University of Illinois Urbana-Champaigne Mass Spectrometry laboratory. All reagents were used directly from commercial sources unless otherwise stated. All reported yields are the average of at least two independent runs.

Preparation of starting materials. Compound 1 was prepared by using literature procedures. ${ }^{1}$ Cyclopentadiene was freshly distilled.

Preparation of Diels-Alder adduct 2.

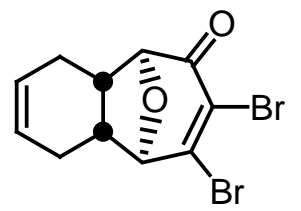

2 To a sealed tube was added 3,4-dibromo-8-oxa-bicyclo[3.2.1]octa-3,6dien-2-one $(1.0 \mathrm{~g}, 3.6 \mathrm{mmol})$. Toluene $(1.5 \mathrm{~mL})$ was added and the reaction stirred until all starting material was in solution. Sulfolene $(1.27 \mathrm{~g}, 10.7 \mathrm{mmol})$ was added and the tube sealed. The tube was heated in an oil bath at $135^{\circ} \mathrm{C}$ for $30 \mathrm{~h}$. The tube was removed from the oil bath and the solution allowed to cool to room temperature. The solvent was removed under reduced pressure and the residue purified by column chromatography $\left(\mathrm{SiO}_{2} ; 100 \mathrm{~g}\right)$ using 5\% ethyl acetate in hexanes as the eluent to afford 2 as a white solid (955 mg, 80\%): $\mathrm{R}_{\mathrm{f}}=.47$ (95:5 Hex:EtOAc); $\mathrm{mp}=69-71{ }^{\circ} \mathrm{C} ;{ }^{1} \mathrm{H} \mathrm{NMR}$ $\left(500 \mathrm{MHz}, \mathrm{CDCl}_{3}\right) \delta$ 6.00-5.93 (m, 2H), $4.68(\mathrm{~s}, 1 \mathrm{H}), 4.45(\mathrm{~s}, 1 \mathrm{H}), 2.59-2.44(\mathrm{~m}, 3 \mathrm{H})$, 
$2.32(\mathrm{dd}, \mathrm{J}=8.5,7.6 \mathrm{~Hz}, 1 \mathrm{H}), 2.01-1.92(\mathrm{~m}, 2 \mathrm{H}) ;{ }^{13} \mathrm{C} \mathrm{NMR}\left(150 \mathrm{MHz}, \mathrm{CDCl}_{3}\right) \delta 187.0$ 151.6, 129.2, 128.9, 123.8, 88.7, 43.9, 40.6, 28.1, 27.8; IR (NaCl, cm $\left.{ }^{-1}\right) 3040.3,2939.3$, 2838.9, 1703.4, 1571.4, 1233.8, 1188.9, 1079.2, 1038.4; HRMS m/z 331.9044 (calculated $\left.\mathrm{C}_{11} \mathrm{H}_{10} \mathrm{Br}_{2} \mathrm{O}_{2}, 331.9048\right)$.

\section{Preparation of Diels-Alder adduct 3.}

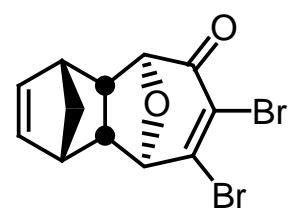

3 To a $10 \mathrm{~mL}$ round bottom flask was added 3,4-dibromo-8-oxabicyclo[3.2.1] octa-3,6-dien-2-one $(1.0 \mathrm{~g}, 3.6 \mathrm{mmol})$. Dichloromethane $(1.5 \mathrm{~mL})$ was added followed by cyclopentadiene $(0.710 \mathrm{~mL}, 10.7 \mathrm{mmol})$. The flask was capped and stirred at $25{ }^{\circ} \mathrm{C}$ for $24 \mathrm{~h}$. The solvent was removed under reduced pressure and the residue purified by column chromatography $\left(\mathrm{SiO}_{2} ; 100 \mathrm{~g}\right)$ using $5 \%$ ethyl acetate in hexanes as the eluent to afford 3 as a white solid $(1.20 \mathrm{~g}, 97 \%): \mathrm{R}_{\mathrm{f}}=.45(95: 5$ Hex:EtOAc); $m p=117-119{ }^{\circ} \mathrm{C} ;{ }^{1} \mathrm{H}$ NMR $\left(500 \mathrm{MHz}, \mathrm{CDCl}_{3}\right) \delta 6.17(\mathrm{dd}, \mathrm{J}=5.6,2.9 \mathrm{~Hz}$, $1 \mathrm{H}), 6.13(\mathrm{dd}, \mathrm{J}=5.6,2.9 \mathrm{~Hz}, 1 \mathrm{H}), 4.55$ (s, 1H), 4.34 (s, 1H), 3.07-3.04 (m, 2H), 2.99 (dd, $\mathrm{J}=7.8,3.9 \mathrm{~Hz}, 1 \mathrm{H}), 2.76(\mathrm{dd}, \mathrm{J}=7.8,4.2 \mathrm{~Hz}, 1 \mathrm{H}), 1.60(\mathrm{dt}, \mathrm{J}=8.5,1.7 \mathrm{~Hz}, 1 \mathrm{H}), 1.53-1.50$ $(\mathrm{m}, 1 \mathrm{H}) ;{ }^{13} \mathrm{C} \mathrm{NMR}\left(150 \mathrm{MHz}, \mathrm{CDCl}_{3}\right) \delta$ 186.8, 152.8, 134.4, 134.2, 124.0, 83.9, 82.6, 53.5, 52.0, 47.6, 45.6, 45.4; IR $\left(\mathrm{NaCl}, \mathrm{cm}^{-1}\right)$ 2973.1, 2890.2, 1710.7, 1361.8, 1223.2; Anal. Calcd. For $\mathrm{C}_{12} \mathrm{H}_{10} \mathrm{Br}_{2} \mathrm{O}_{2}$ : C, 41.65; H, 2.91. Found: C, 41.99; H, 2.90.

\section{Preparation of Diels-Alder adduct 4.}

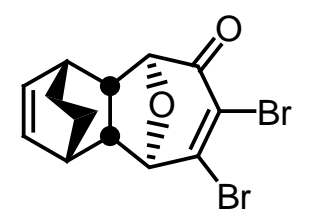

4

To a sealed tube was added 3,4-dibromo-8-oxa-bicyclo[3.2.1]octa-3,6dien-2-one $(1.0 \mathrm{~g}, 3.6 \mathrm{mmol})$. Toluene $(1.5 \mathrm{~mL})$ was added and the reaction stirred until all starting material was in solution. Cyclohexadiene $(1.01 \mathrm{~mL}, 10.7 \mathrm{mmol})$ was added and the tube sealed. The tube was heated in an oil bath at $130{ }^{\circ} \mathrm{C}$ for $30 \mathrm{~h}$. The tube was removed from the oil bath and the solution allowed to cool to room temperature. The solvent was removed under reduced pressure and the residue purified by column chromatography $\left(\mathrm{SiO}_{2} ; 100 \mathrm{~g}\right)$ using $5 \%$ ethyl acetate in hexanes as the eluent to afford 4 
as a white solid $(1.22 \mathrm{~g}, 95 \%): \mathrm{R}_{\mathrm{f}}=.47$ (95:5 Hex:EtOAc); $\mathrm{mp}=130-132{ }^{\circ} \mathrm{C} ;{ }^{1} \mathrm{H}$ NMR $\left(500 \mathrm{MHz}, \mathrm{CDCl}_{3}\right) \delta$ 6.25-6.22 (m, 2H), $4.67(\mathrm{~s}, 1 \mathrm{H}), 4.45(\mathrm{~s}, 1 \mathrm{H}), 2.92-2.87(\mathrm{~m}, 1 \mathrm{H})$, 2.84-2.81 (m, 1H), $2.46(\mathrm{dd}, \mathrm{J}=8.2,2.7 \mathrm{~Hz}, 1 \mathrm{H}), 2.28(\mathrm{dd}, \mathrm{J}=8.2,2.7 \mathrm{~Hz}, 1 \mathrm{H}), 1.59-1.45$ $(\mathrm{m}, 2 \mathrm{H}), 1.30-1.23(\mathrm{~m}, 2 \mathrm{H}) ;{ }^{13} \mathrm{C} \mathrm{NMR}\left(150 \mathrm{MHz}, \mathrm{CDCl}_{3}\right) \delta 186.8,152.4,132.7,131.8$, 124.6, 87.3, 86.2, 48.4, 44.9, 33.9, 33.7, 24.7, 23.8; IR ( $\left.\mathrm{NaCl}, \mathrm{cm}^{-1}\right)$ 3046.3, 2938.2, 2866.4, 1703.7, 1566.0, 1227.8, 1051.4; Anal. Calcd. For $\mathrm{C}_{13} \mathrm{H}_{12} \mathrm{Br}_{2} \mathrm{O}_{2}: \mathrm{C}, 43.37 ; \mathrm{H}, 3.36$. Found: C, 43.45; H, 3.33 .

\section{Preparation of Diels-Alder adduct 5.}

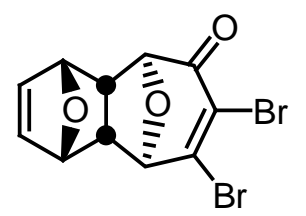

5

To a sealed tube was added 3,4-dibromo-8-oxa-bicyclo[3.2.1] octa-3,6dien-2-one $(1.0 \mathrm{~g}, 3.6 \mathrm{mmol})$. Benzene $(1.5 \mathrm{~mL})$ was added and the reaction stirred until all starting material was in solution. Furan $(0.779 \mathrm{~mL}, 10.7 \mathrm{mmol})$ was added and the tube sealed. The tube was heated in an oil bath at $100{ }^{\circ} \mathrm{C}$ for $5 \mathrm{~d}$. The tube was removed from the oil bath and the solution allowed to cool to room temperature. The solvent was removed under reduced pressure and the residue purified by column chromatography $\left(\mathrm{SiO}_{2} ; 100 \mathrm{~g}\right.$ ) using $33 \%$ ethyl acetate in hexanes as the eluent to afford 5 as a white solid (746 mg, 60\%): $\mathrm{R}_{\mathrm{f}}=.26(2: 1 \mathrm{Hex}: \mathrm{EtOAc}) ; \mathrm{mp}=161-163 \quad{ }^{\circ} \mathrm{C} ;{ }^{1} \mathrm{H}$ NMR $(500 \mathrm{MHz}$, $\left.\mathrm{CDCl}_{3}\right) \delta 6.47(\mathrm{dd}, \mathrm{J}=5.9,1.7 \mathrm{~Hz}, 1 \mathrm{H}), 6.43(\mathrm{dd}, \mathrm{J}=5.9,1.7 \mathrm{~Hz}, 1 \mathrm{H}), 5.04(\mathrm{dd}, \mathrm{J}=10.7$, $4.9 \mathrm{~Hz}, 2 \mathrm{H}), 4.50$ (s, 1H), 4.27 (s, 1H), 3.19 (dd, J= 7.8, $4.9 \mathrm{~Hz}, 1 \mathrm{H}), 2.98$ (dd, J= 7.8, 4.9 $\mathrm{Hz}, 1 \mathrm{H}) ;{ }^{13} \mathrm{C}$ NMR $\left(150 \mathrm{MHz}, \mathrm{CDCl}_{3}\right) \delta 185.9,151.8,134.5,134.4,124.2,81.6,80.3$, 79.6, 79.4, 51.8, 47.6; IR ( $\left.\mathrm{NaCl}, \mathrm{cm}^{-1}\right)$ 3005.0, 2955.6, 1711.5, 1362.1, 1223.0; Anal. Calcd. For $\mathrm{C}_{11} \mathrm{H}_{8} \mathrm{Br}_{2} \mathrm{O}_{3}$ : C, 37.97; H, 2.32. Found: C, 38.14; H, 2.32.

\section{Preparation of Diels-Alder adduct 6.}

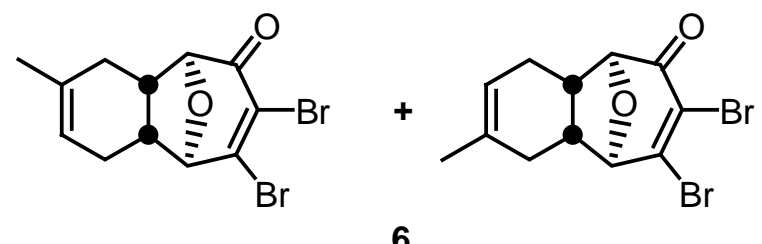

To a sealed tube was added 3,4-dibromo-8oxa-bicyclo[3.2.1]octa-3,6-dien-2-one $(1.0 \mathrm{~g}, 3.6 \mathrm{mmol})$. Toluene $(1.5 \mathrm{~mL})$ was added and the reaction stirred until all starting material was in solution. Isoprene $(1.22 \mathrm{~mL}$, 
$10.7 \mathrm{mmol}$ ) was added and the tube sealed. The tube was heated in an oil bath at $110^{\circ} \mathrm{C}$ for $5 \mathrm{~d}$. The tube was removed from the oil bath and the solution allowed to cool to room temperature. The solvent was removed under reduced pressure and the residue purified by column chromatography $\left(\mathrm{SiO}_{2} ; 100 \mathrm{~g}\right)$ using $5 \%$ ethyl acetate in hexanes as the eluent to afford a mixture of regioisomers 6 as a white solid $(746 \mathrm{mg}, 60 \%): \mathrm{R}_{\mathrm{f}}=.55(95: 5$ Hex:EtOAc); ${ }^{1} \mathrm{H}$ NMR $\left(500 \mathrm{MHz}, \mathrm{CDCl}_{3}\right) \delta$ 5.60-5.57 (m, 2H), $4.67(\mathrm{~s}, 1 \mathrm{H}), 4.43(\mathrm{~s}$, $1 \mathrm{H}), 2.51-2.25(\mathrm{~m}, 8 \mathrm{H}), 2.05-1.87(\mathrm{~m}, 4 \mathrm{H}), 1.75(\mathrm{~d}, \mathrm{~J}=7.3 \mathrm{~Hz}, 6 \mathrm{H}) ;{ }^{13} \mathrm{C} \mathrm{NMR}(150 \mathrm{MHz}$, $\left.\mathrm{CDCl}_{3}\right) \delta 187.14,187.12,151.9,151.7,137.6,137.2,123.8,123.7,121.7,121.4,88.8$, 88.7, 88.3, 88.2, 44.1, 44.0, 40.8, 40.6, 33.6, 33.2, 28.5, 28.2, 23.07, 23.06; IR ( $\mathrm{NaCl}, \mathrm{cm}^{-}$ 1) 2931.0, 2839.2, 1703.9, 1571.1, 1234.5, 1192.5; HRMS m/z 345.9204 (calculated $\left.\mathrm{C}_{12} \mathrm{H}_{12} \mathrm{Br}_{2} \mathrm{O}_{2}, 345.9204\right)$.

\section{Procedure for Diels-Alder Competition Studies.}

3,4-dibromo-8-oxa-bicyclo[3.2.1]octa-3,6-dien-2-one (1.0 eq) and a bridged dienophile 8-12 (1.0 eq) were dissolved in methylene chloride $(3.6 \mathrm{M})$. Cyclopentadiene (1.0 eq) was added and the reaction was stirred at $25^{\circ} \mathrm{C}$ for $24 \mathrm{~h}$. The solvent was removed under reduced pressure and the residue purified by column chromatography $\left(\mathrm{SiO}_{2} ; 10 \mathrm{~g}\right)$ using $5 \%$ ethyl acetate in hexanes as the eluent. The compounds isolated were $3(95 \%)$ and 812.

\section{Preparation of Dialdehyde 13.}

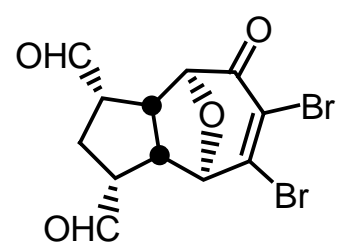

13 To a $10 \mathrm{~mL}$ round bottom flask was added THF $(3.0 \mathrm{~mL})$ and $t \mathrm{BuOH}$ $(1.0 \mathrm{~mL})$. 4-methylmorpholine-N-oxide $(51.0 \mathrm{mg}, 0.434 \mathrm{mmol})$ was added and the mixture was stirred at $25{ }^{\circ} \mathrm{C}$. Osmium tetraoxide, $4 \mathrm{wt} . \%$ in water, $(0.092 \mathrm{~mL}, 0.0145$ $\mathrm{mmol})$ was added followed by $2(100 \mathrm{mg}, 0.289 \mathrm{mmol})$. The solution was stirred at $25{ }^{\circ} \mathrm{C}$ for $2 \mathrm{~h}$. Sat. sodium bisulfite $(0.500 \mathrm{~mL})$ was added and the solution stirred for 30 min. The layers were separated and the aqueous layer was extracted with EtOAc $(3 \times 10$ $\mathrm{mL}$ ). The combined organics were dried over sodium sulfate and concentrated to give the crude diol as a white solid (112 mg, 102\%). The diol was dissolved in THF (3.0 mL) 
and water $(1.0 \mathrm{~mL})$. Sodium periodate $(93 \mathrm{mg}, 0.434 \mathrm{mmol})$ was added and the solution was stirred at $25^{\circ} \mathrm{C}$ for $10 \mathrm{~min}$. The white precipitate was filtered off and washed with EtOAc $(3 \times 10 \mathrm{~mL})$. The combined organics were washed with brine, dried over sodium sulfate and concentrated under reduced pressure to give $\mathbf{1 3}$ as a white solid (96 mg, 88\%): $\mathrm{R}_{\mathrm{f}}=0.20$ (1:2 Hex:EtOAc); mp= decomposed above $95{ }^{\circ} \mathrm{C} ;{ }^{1} \mathrm{H}$ NMR $\left(500 \mathrm{MHz}, \mathrm{CDCl}_{3}\right)$

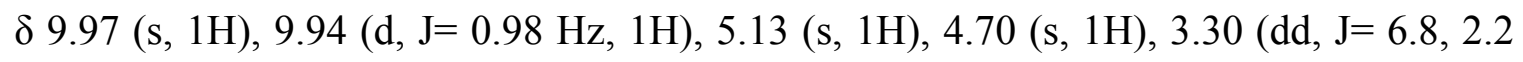
$\mathrm{Hz}, 1 \mathrm{H}), 3.15-3.00(\mathrm{~m}, 3 \mathrm{H}), 2.26-2.21(\mathrm{~m}, 2 \mathrm{H}) ;{ }^{13} \mathrm{C} \mathrm{NMR}\left(150 \mathrm{MHz}, \mathrm{CDCl}_{3}\right) \delta 200.5$, 199.7, 185.6, 124.6, 84.1, 83.2, 53.6, 52.6, 48.6, 45.6, 27.3; IR ( NaCl, $\left.\mathrm{cm}^{-1}\right)$ 3054.9, 2977.8, 1707.8, 1263.3; HRMS m/z 375.8950 (calculated $\mathrm{C}_{12} \mathrm{H}_{10} \mathrm{Br}_{2} \mathrm{O}_{4}, 375.8946$ ). 


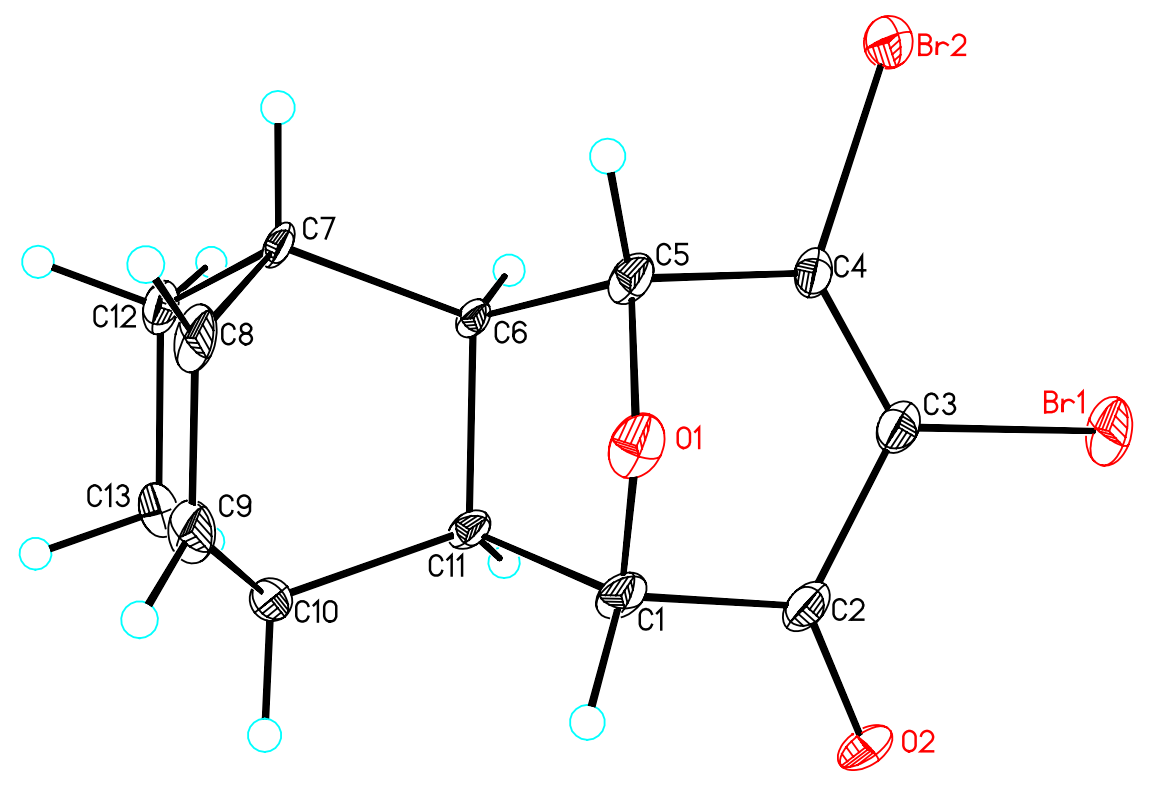

Figure 1: X-ray structure of compound 4.

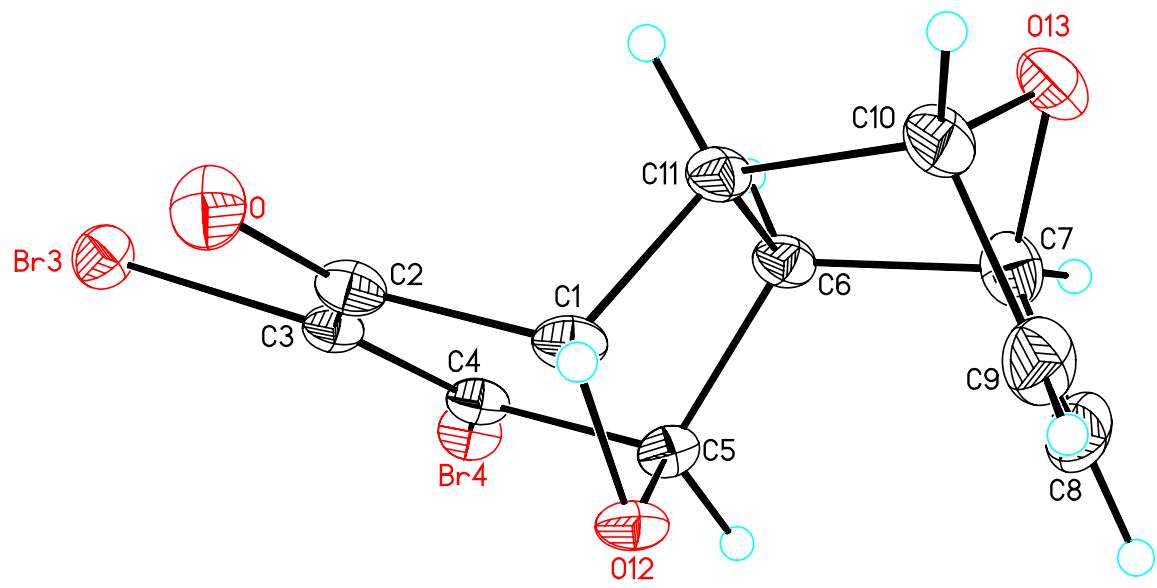

Figure 2: X-ray structure of compound 5. 

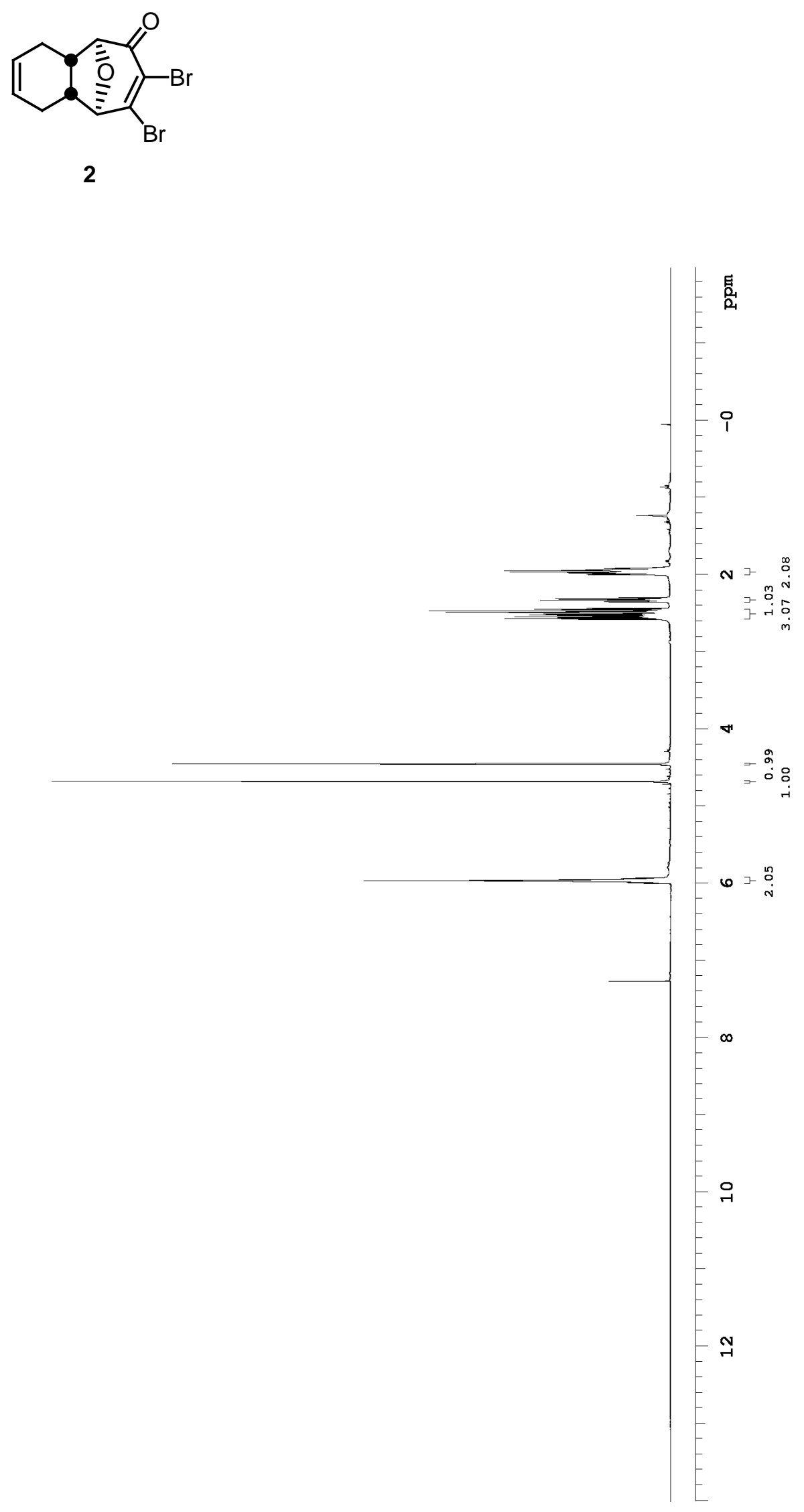

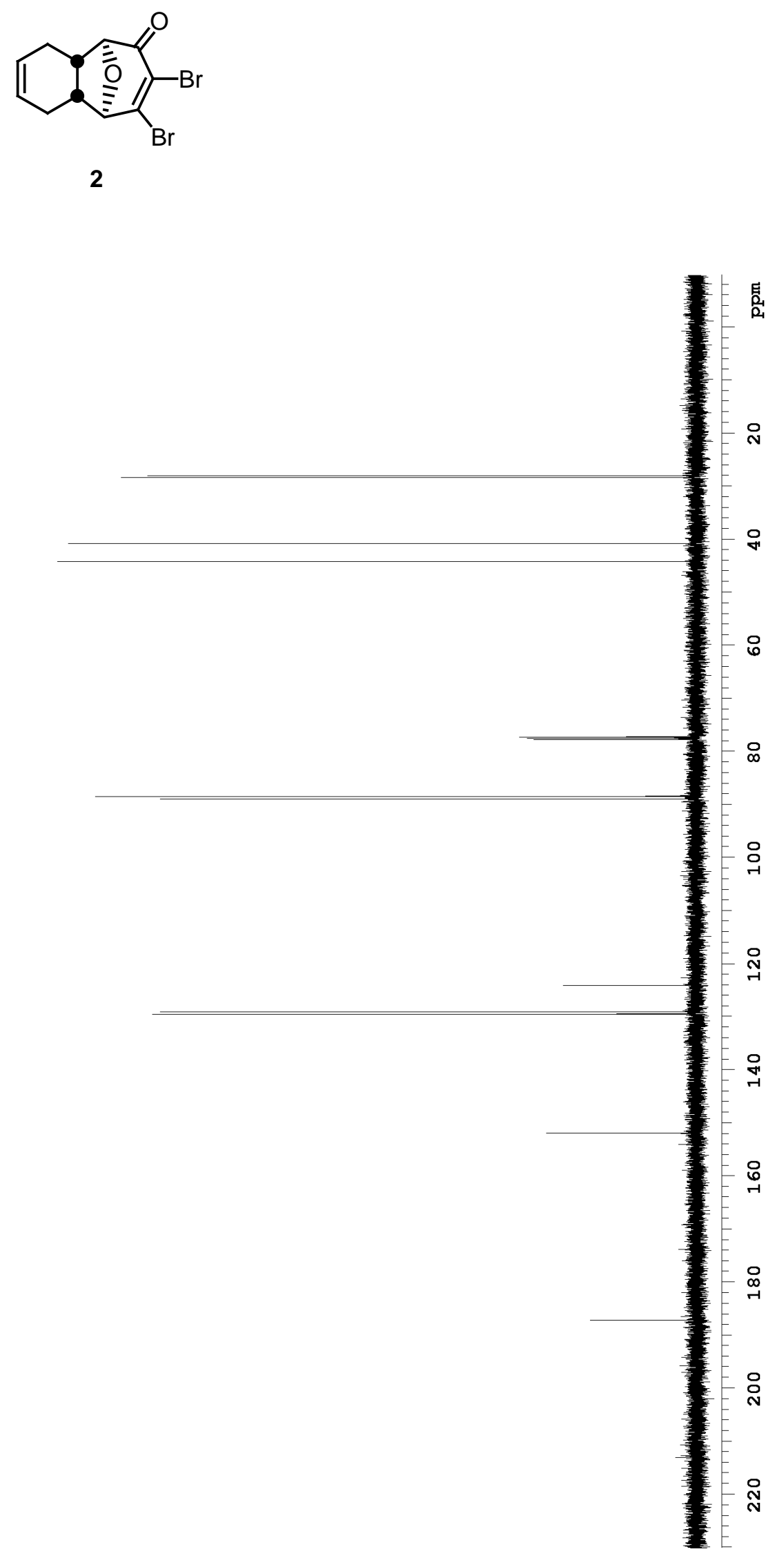
$\underbrace{\mathrm{Br}}_{\mathrm{Br}}$

3

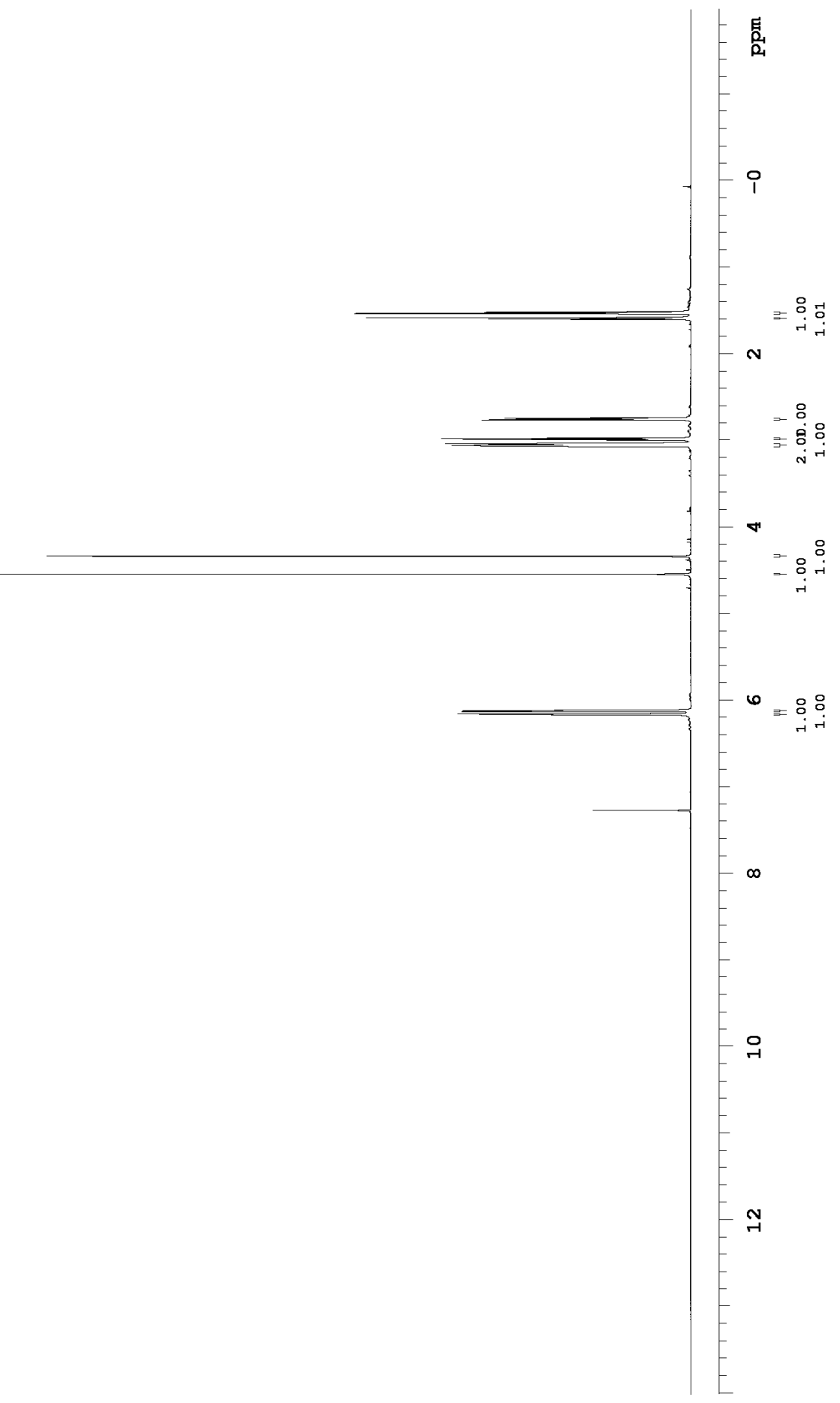




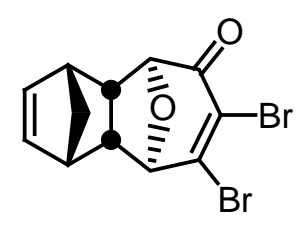

3

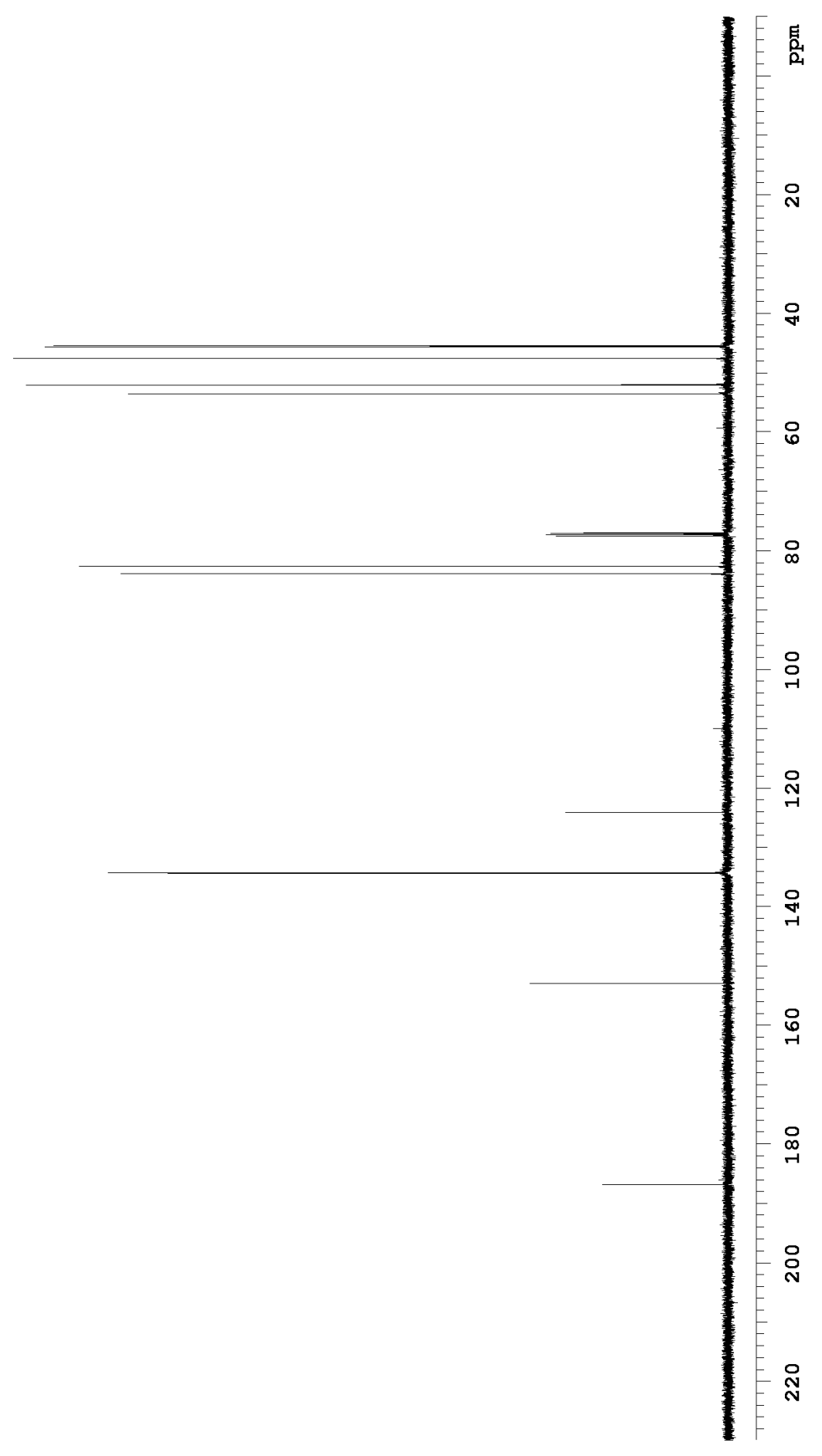

S10 
$\underbrace{\mathrm{Br}}_{\mathrm{Br}}$

4

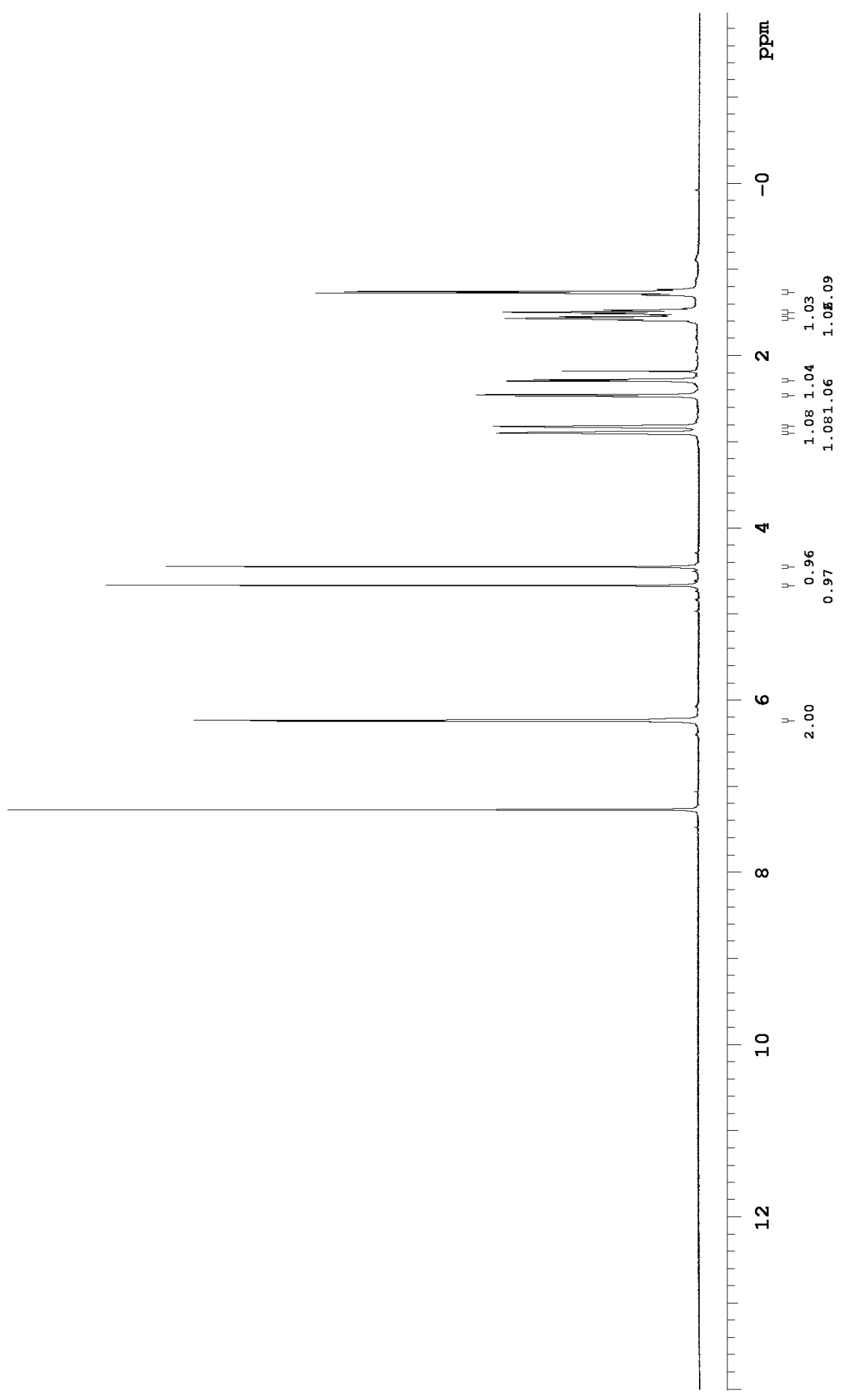




$$
1
$$



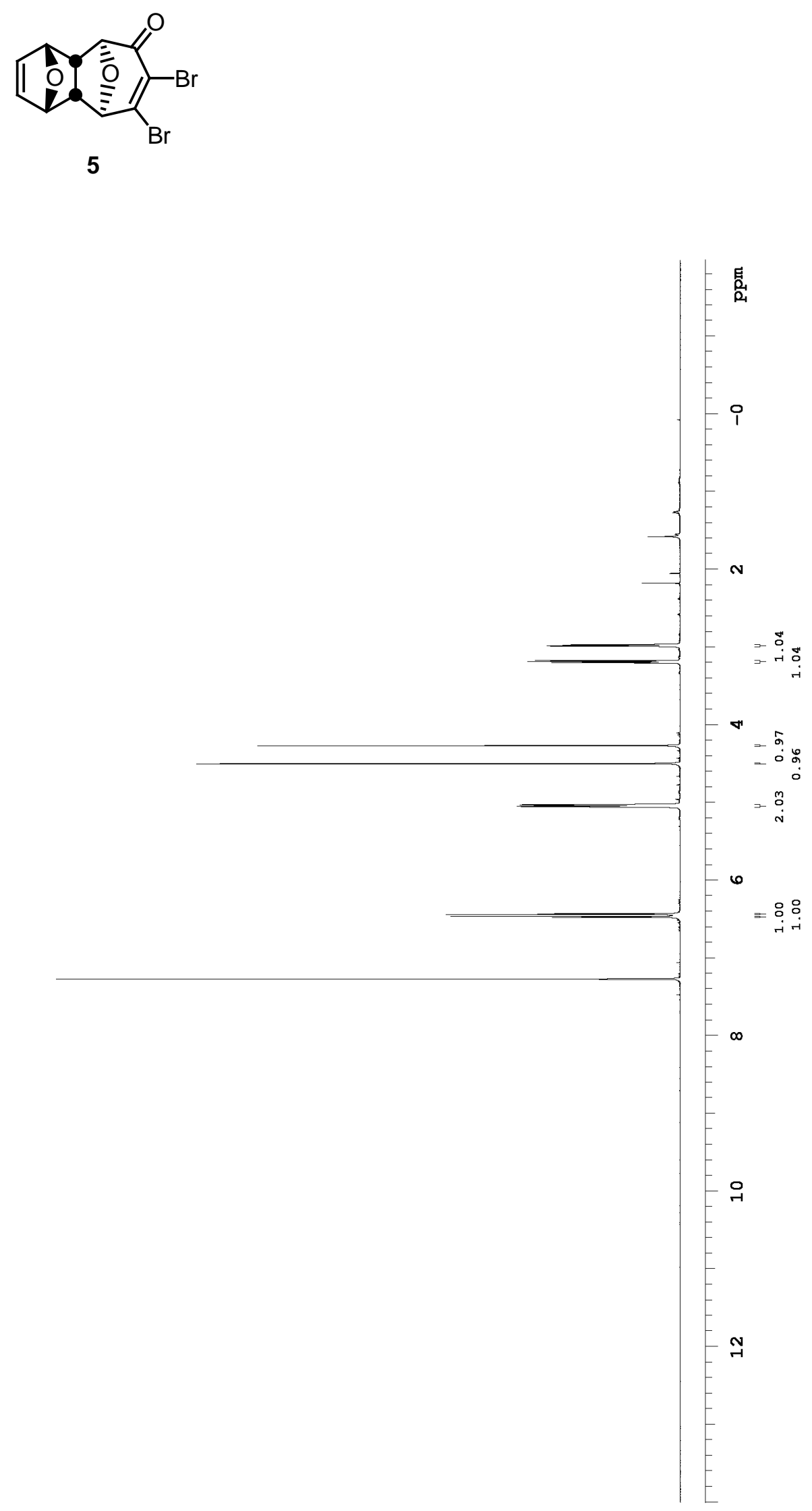

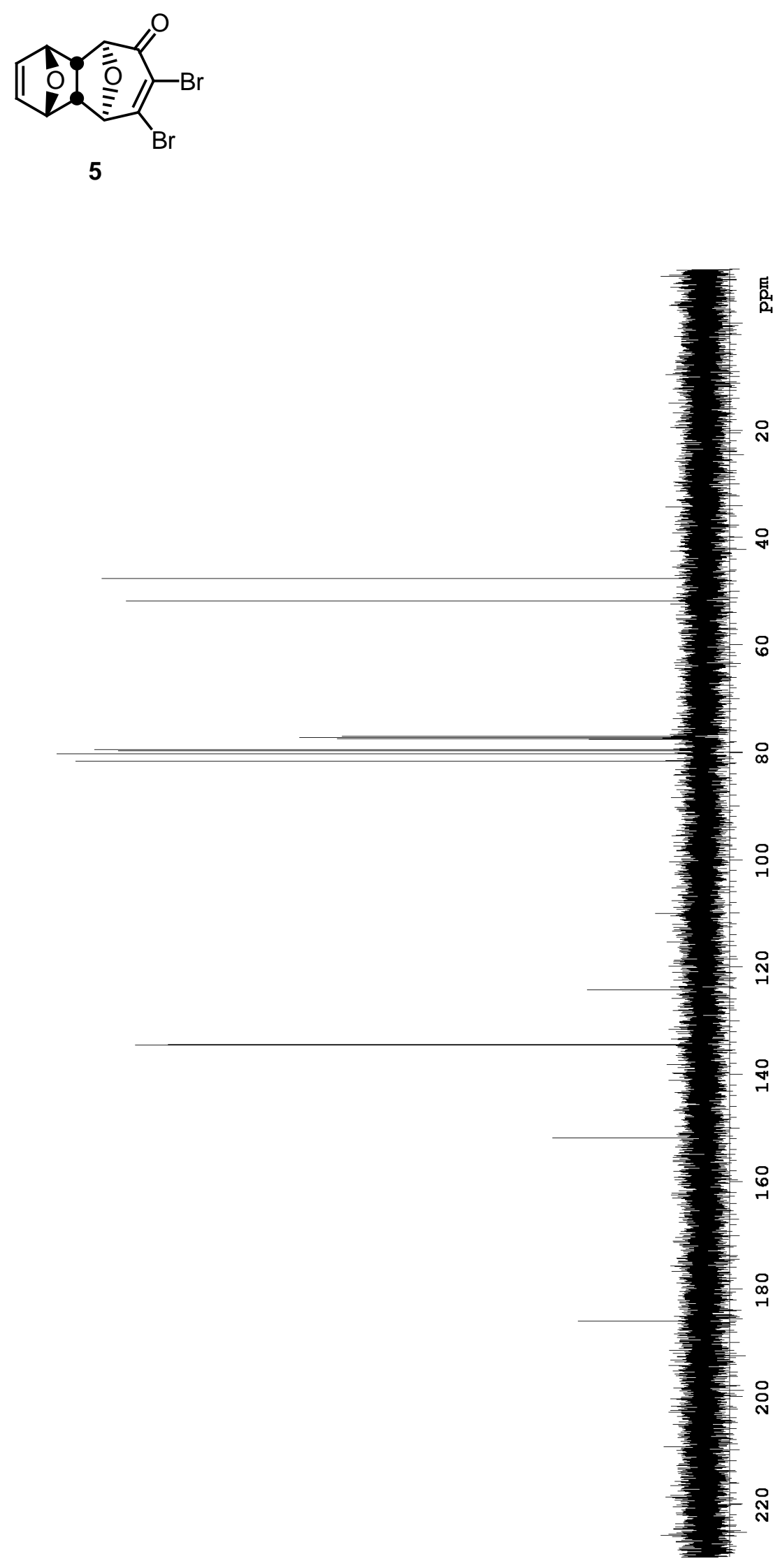


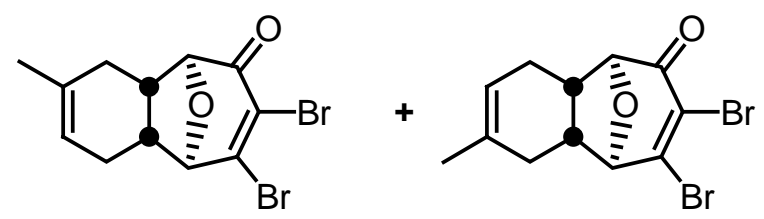

6

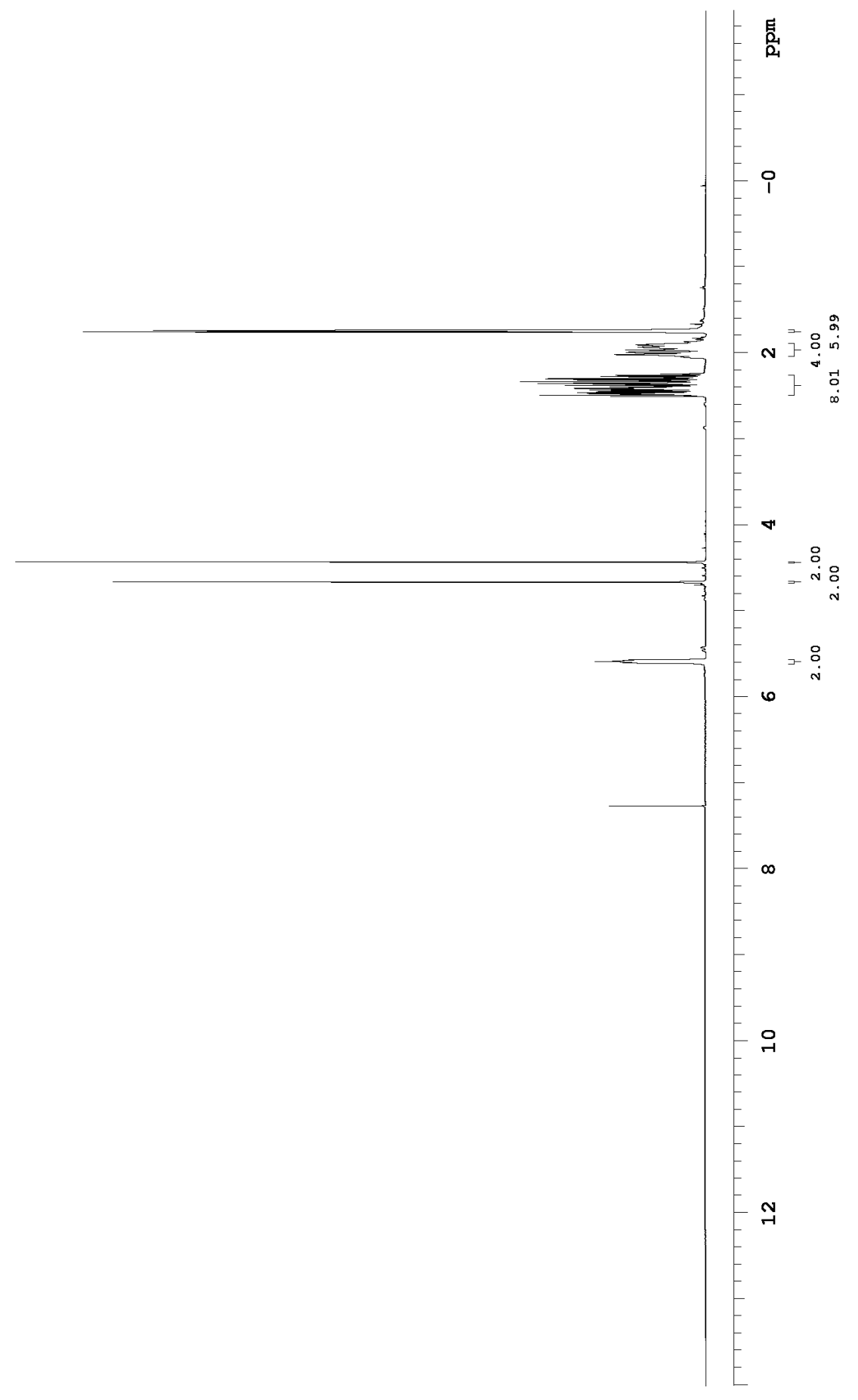



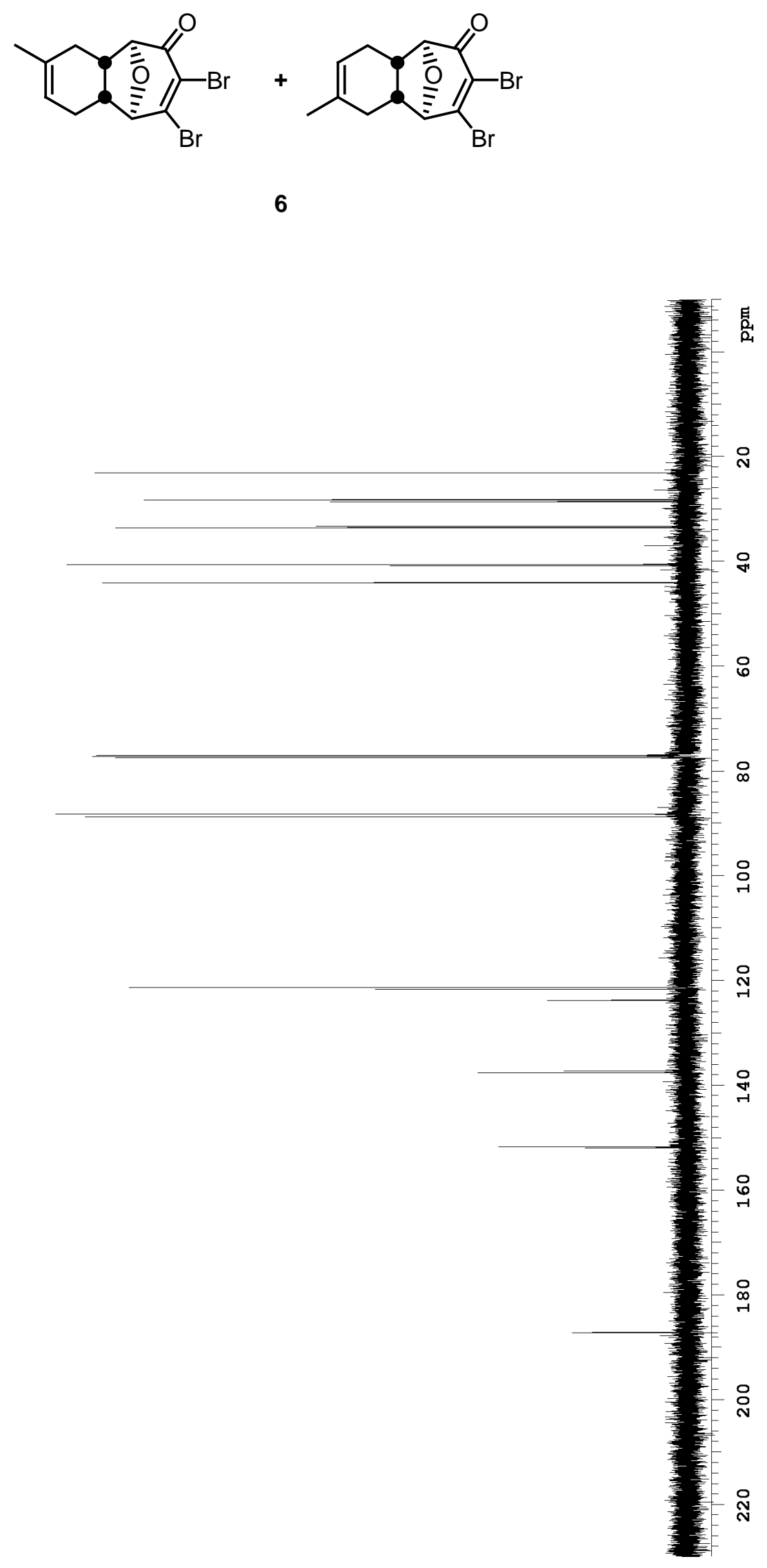


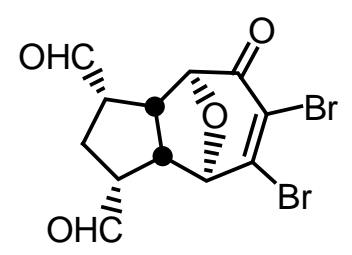

13

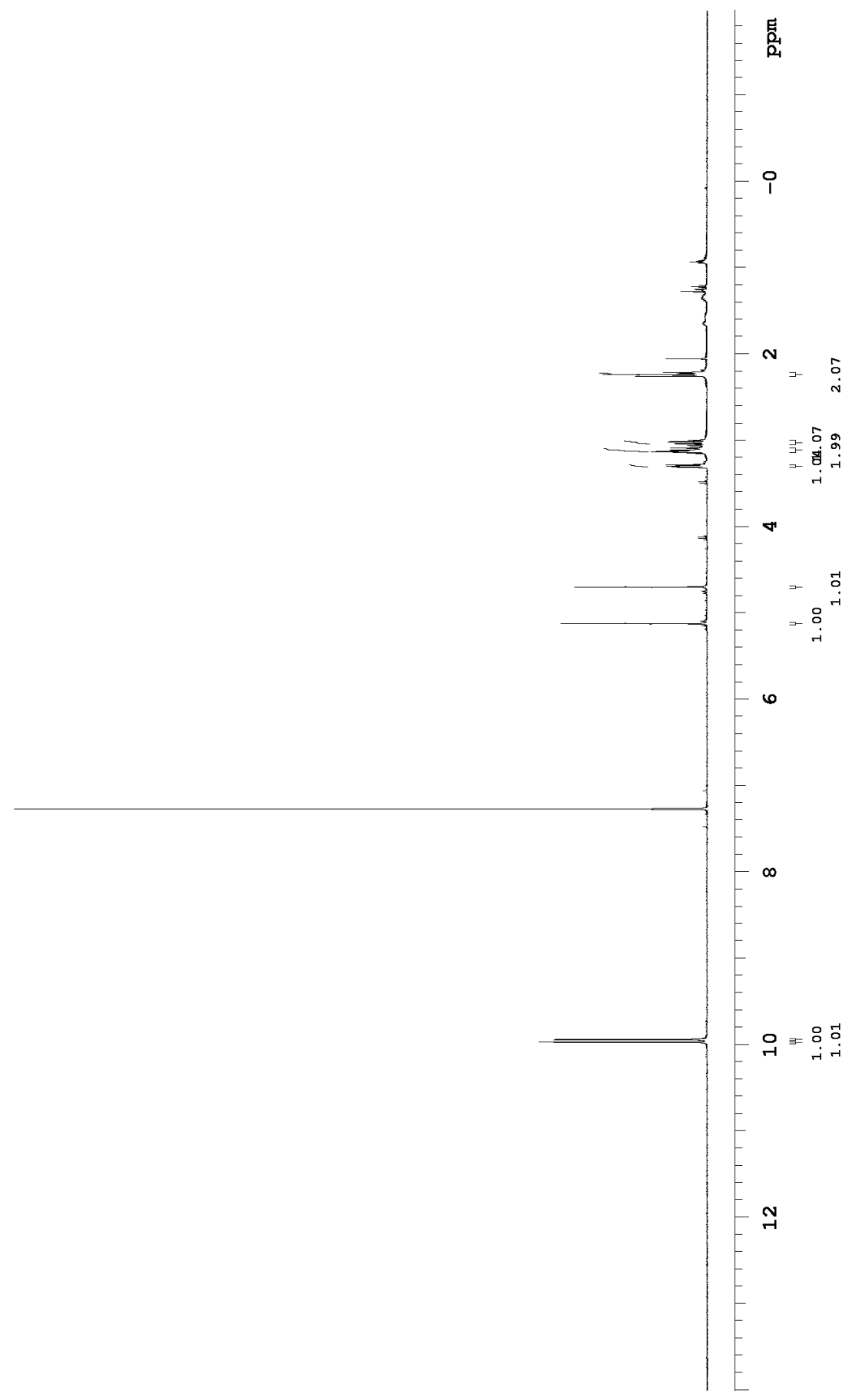




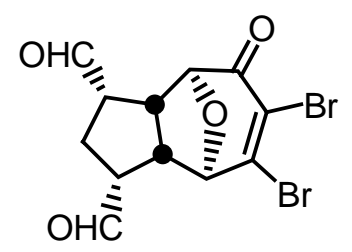

13

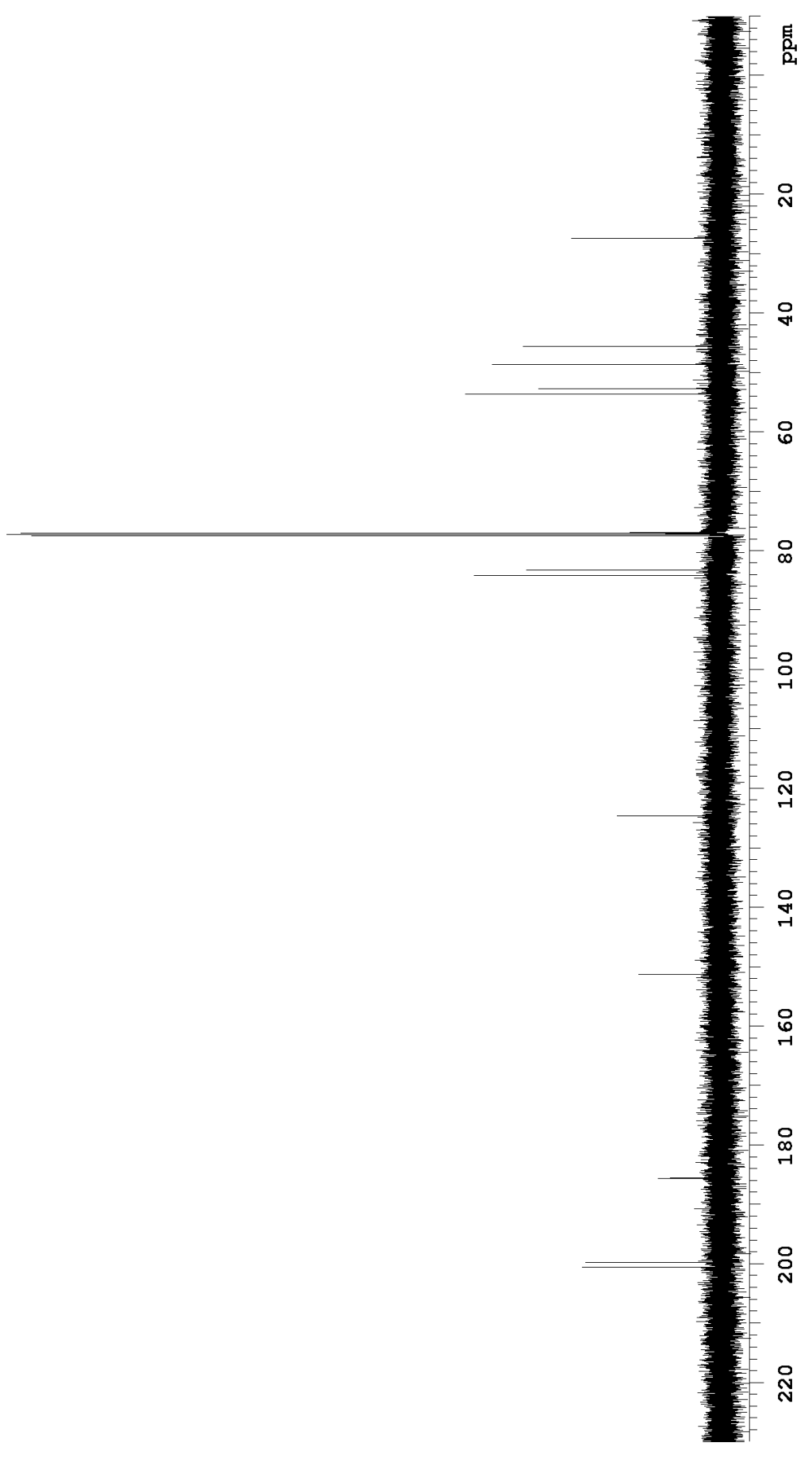




\section{References:}

1. Orugunty, R. S.; Wright, D. L.; Battiste, M. A.; Helmich, R. J.; Abboud, K. J. Org. Chem. 2004, 69, 406-416. 